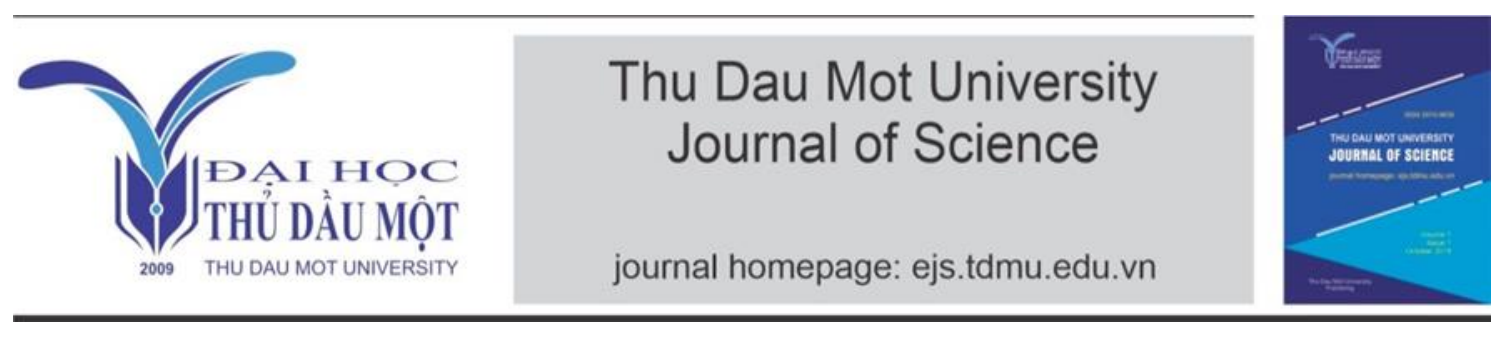

\title{
Symbolic meanings of Holy Temple in Cao Dai Tay Ninh Holy See
}

by Nguyễn Thái Bảo (HCMC University of Social Sciences and Humanities)

Article Info: $\quad$ Received 15 April 2021, Accepted 2 Sep 2021, Available online 15 Sep 2021

Corresponding author: hnthu76@hcmussh.edu.vn

https://doi.org/10.37550/tdmu.EJS/2021.03.218

\begin{abstract}
Dai Dao Tam Ky Pho Do [The Great Way of The Third Amnesty Era] (shortly Caodaism) is an indigenous religion established in southern Vietnam in the early $20^{\text {th }}$ century. Being one of the new religions in the region, Caodaism has been constantly developing and attracting quite a great number of followers of over three million.

The doctrine of Caodaism is a synthesis of the Three Religions, e.g. Confucianism, Buddhism and Taoism together with elements from some other religions. The doctrine is not only shown in scriptures, religious structure, but also expressed through symbols in architecture, rituals and costumes. To a certain extent, it is thus essential to understand the symbolism of the Holy Temple - the most important one of the symbolism system so that we can fully comprehend Caodaism.

The Temple is the most solemn and sacred place in Cao Dai Tay Ninh Holy See. It carries both philosophical and esoteric meanings as an emblem of cultural syncretism. The study of the Holy Temple symbol will elaborate further Caodaist doctrines in a relationship with the cultural context of the Southern region.
\end{abstract}

Keywords: Caodaism, symbol

\section{Introduction}

Vietnam is a multi - religious country. The religions have their significant influences 
throughout Vietnam historical, cultural and social upheavals. The Caodaism (the official name: The Great Way of the Third Amnesty Era) was founded in Southern Vietnam in the early years of the $20^{\text {th }}$ century at a time of economic, political, social and ideological standstills. As a result, the emergence of new Religion rapidly gathered mass adherence of people in Southern Vietnamese. It was 90 years since inauguration day, Caodaism has considerably spread over Vietnam and other countries with estimated 3 million followers and more than 500 worship facilities.

By the way of gathering true doctrines of Confucianism, Buddhism, Taoism, Christianity and other religions, Caodaism creates a new syncretic doctrine which clearly expressed via the objective towards the unity of "Three Great Religions and of the Five Branches of the Great Way". Nevertheless, the cultural syncretism spirit of Caodaism does not only manifest in their doctrine but also in rituals, costumes, organizations and especially, the architecture of their worship facilities with a symbolism system. Thus, we need to decode symbolic meanings to comprehend Caodaism as Anthropologist Cliffor Geertz mentioned that "symbol is a vehicle of cultural expression and conveyance” (Trần Khánh Hưng, 2014) or as Dinh Hong Hai's idea "Symbols are representative signs which people created throughout their life, and influenced on cultural life” (Đinh Hồng Hải, 2014).

Many scholars have conducted research, from diverse perspectives, about Caodaism in the interrelationship with Southern culture. In the extent of this study, I attempt to explain the symbolic meanings of the Holy Temple. The Temple is referred as the most solemn and sacred place on account of religious symbolism which was designed and decorated under the comprehensive guide of Divine Beings via Cơ Bút (spiritism séance). The decoding of the Holy Temple symbol will contribute further references for academic teaching and research about Caodaism in Vietnam.

\section{Literature reviews}

Caodaism is an indigenous religion and this topic draw many studies from diverse perspectives of Vietnamese and foreign researchers for long. There are some significant studies as: "Tổng quan Cao Đài giáo" [An Overview of Caodaism] by Đồng Tân published in 1980, "Bước đầu tìm hiểu Đạo Cao Đài" [A first step to understanding Caodaism] by Dang Nghiem Van (Editor -in -Chief) published in 1995, "Lê̂ hôi Cao Đài nhìn tù góc độ văn hoá" [Caodaism Festivals from cultural perspective] - a thesis of Nguyen Manh Tien in 2006, "Đời sống tôn giáo của tín đồ đạo Cao Đài trong bối cảnh văn hóa Nam Bộ" [Religious life of Caodaists in the cultural schemes in Southern Vietnam] - a master thesis of Huynh Ngoc Thu in 2010. These studies are valuable sources for academic references. 
In addition, the author have developed several studies, articles about Caodaism including: Nghi thức giải oan của đạo Cao Đài Tây Ninh [The ritual of Giải oan in Caodaism in Tay ninh, "Giải" means being free, "oan" means sins] published on Journal of Social sciences and Humanities No. 60 (12/2013), Sụ duy lý trong việc hành thiện của người tín đồ Cao Đài Tây Ninh [Rationalism in good deeds of Caodaists in Tay ninh] published on Proceedings of science conference in 2015 hosted by Institute for Religious studies, Master thesis on Ethnology "Tính nhập thế của Cao Đài Tây Ninh" [Social engagement of Caodaism - Tay ninh] in 2015.

\section{Methods}

During this study, we used several featured methods in Anthropology and Ethnology as follow as:

Participant observation method: this method requires researcher must live in an observed -area in a certain time to gather accurate information in the role of society member.

In-Depth Individual Interviews: with targeted dialogues or questions in the purpose of gathering individual information. This method usually developed along with participant observation during the fieldwork in order to know how Caodaists think about symbols.

\section{Results}

\section{An overview of the Holy Temple:}

Caodaist main church - Holy Temple is located inside Caodaism Holy See in Long Thanh Bac ward, Hoa Thanh town, Tay Ninh province. Through historical references, Divine Being decided on the land and gave instruction to build the Holy Temple via spiritist séance. The initial plan expected the length of Holy Temple to be 135 meters with 27 meters wide and 36 meters high. However, Caodaists could not afford this grand construction plan at that time, instead it was resized into 22 meters wide, 97,5 meters in length and 27 meters high. In 1931, the construction was started and has been interrupted several times by the war and lack of funds. Until 1955, Ho -Phap Pham Cong -Tac completed the construction and held a grand inauguration of the Holy Temple. The architectural structure of the Holy Temple is designed with 3 main palaces: Hiep -Thien -Dai (Heaven Union Palace), Cuu -Trung -Dai (Nine Spheres Palace) and Bat -Quai -Dai (Eight Trigram Palace).

\section{Heaven Union Palace}

Heaven Union Palace is the first part of Holy Temple, it has two Towers with the same height of 27 meters: Bach -Ngoc -Chung -Dai on the left (Bell Tower) and Loi -Am - 
Co -Dai on the right (Drum Tower). The ground floor of each Tower has a flower decorated rectangle window which was carved with the word "Cao" (Cao means High) in the middle of Drum Tower and the word "Dai" (Dai means Palace) is likewise in Bell Tower. These two words were carved in Hanzi/ Chinese characters. Above the flower-decorated window of Bell Tower, there are four carved circle patterns with four words "Bach Ngoc Chung Dai " in each one, this decoration of Drum Tower is similar, but instead with 4 words "Loi Am Co Dai". The front of Bell Tower, on the second floor, there is a carved statue of Acting Pope Le Van Trung (Religious name: Thuong Trung Nhut), he wears religious costume, stands on the globe with Celestial Book on his right hand. Similarly, in Drum Tower is a carved statue of Female Cardinal Lam Huong Thanh, she wears religious costume, stands on the globe with a flower branch on her right hand and a flower basket on her left hand. The two superior dignitaries were honoured for their contribution to the founding of Caodaism and the construction of Holy Temple. In front of each Tower, at the third floor, there are two flower-shaped air holes. On the fourth flour, there is a huge drum called Loi -Am -Co in Drum Tower and a huge bell called Bach -Ngoc - Chung in Bell Tower. The drum and the bell serve to ritual purposes. There is a $\mathrm{Wu}$ lou statue on the top of Bell Tower and a flower basket statue on the top of Drum Tower.

In front of the main door of Holy Temple, there are four column pillars (two of them are parallel at each side). The colourful and delicate sculpture of a dragon wrapped around each pillar. There are five steps leading to the entryway, on the right side is the statue of civil door God with a gentle face, wears a gold headdress and ancient marshal's armour, one hand holds a halberd, on the left side is the statue of martial door God with an ugly face, wears ancient marshal's armour, one hand holds an axe, the other holds jade seal. There is a half -moon balcony above four pillars called Labour Palace, outside the balcony was sculpted by eight sculptures representing to eight major professional categories in the society as follows as: shi (gentry scholars), the nong (peasant farmers), the gong (artisans and craftsmen), and the shang (merchants and traders), fisherman, woodman, peasant, herdsman. The National flag and Caodaism flag appear in the middle of the balcony.

Divine Eye was sculpted between the Drum and Bell Tower, on two sides were carved with two parallel sentences in Hanzi characters meant to:

Following Caodaism/ High Palace, a hundred of humans ancestry over ten directions venerate the righteous teaching.

Heaven initiated Great Way/Religion, five branches and three teachings unifies at Flower Dragon Assembly.

Above these sentences, there is a character of "Nhân" (Ren/ Benevolence) on the right 
and "Nghĩ" (Yi/ Righteousness) on the left.

Caodaism's objective towards "Nhân - Nghĩa" was interpreted via following sentence:

To spread the benevolence over four directions, Caodaism encourages benevolence to contribute to the development of the country.

To extend the righteousness to a myriad of years, the Great Way of Third Universal Salvation esteems the righteousness to honor the country.

Above the words of "Nhân" and "Nghĩa", there are two lines, one in Vietnamese, one in Hanzi, writing the official name of Caodaism "Great Way of Third Universal Salvation". On the top of the lines is a symbol of Caodaism's Co -Phap (Ancient Dharma) which represents Three Religions, combined with: an Alms Bowl, a Feather Whisk and an Annals of Spring and Autumn. Inside the second floor of Heaven Union Palace, there is a Tieu Dieu court where Superior Heavenly -appointed Dignitaries communicated to Divine Beings via spiritism séance). On the top of Tieu Dieu Court is the statue of Maitreya Buddha sitting on a tiger, this figure monumentalizes the inauguration year of Caodaism (the Lunar year of Tiger - 1926).

Before every ritual service, dignitaries and believers have to enter into Tinh Tam Court in Heaven Union Palace, the name "Tinh Tam" indicates that this court is a place for people to seek peace of mind. In the middle is a dominant picture depicting Three Saints of Caodaism who presented to humanity in the agreement with God called Heaven Humanity agreement. The Three Saints are: Trang Trinh Nguyen Binh Khiem (Thanh Son $\mathrm{Dao} \mathrm{Si}$ ) who holds a brush and writes in Hanzi characters "Above the heaven, below the heaven, Love and Justice", Victor Hugo - the compassionate French poet and writer (also known as Nguyet Tam Chon Nhon) who holds a quill and writes in French character with the same message above; and Chinese revolutionist Sun Yat Sen (his spiritual name is Trung Son Chon Nhon), he holds an ink stone surrounding by glory.

The altars of Heaven Union Palace's deceased -Dignitaries were placed in the first floor of this Palace. The musicians play ritual music before the altars during a service. In the middle of Heaven Union Palace's ground floor, a statue of His Holiness Ho -Phap Pham -Cong - Tac faced to the sanctum, He dressed on great ceremonial costumes, stands on lotus -flower throne and his right hand holds the staff of Kim Tien, or the Rule Over Evil.

The Ho -Phap steps on two heads of the serpent written as Anger, Sadness, His both hands press down the two written as Jealousy, Lust; these four heads symbolizes to four negative passions that should be conquered; three heads rising up represent to three positive passions Beatitude, Love and Joy that humans should nurtures. Behind the HO PHAP's throne is a sculpture of the character "Khi" (Ch'i) meant to the veneration of "sustaining breath of the cosmos". There is a pair of parallel calligraphy panels with two 
sentences in Hanzi, it meant to:

Buddha taught that it must be based on the era to save humans and practice righteous dharma.

The power in the Religion is to decide on the era of preservation of righteous dharma and rule over the evils.

On the right side, the statue of His Excellency Thuong - Pham Cao - Quynh - Cu stands on lotus -flower throne ahead of the Phuon Thuong -Pham, dressed on great ceremonial costumes; his right hand holds the Long Tu Phien (Fan of Exteriorisation) with the Phat Chu (Feather Whisk) on the top; his left hand holds the string of beads called Tu Bi (mercy). On the left side is the statue of His Excellency Thuong -Sanh Cao -Hoai Sang stands on lotus -flower throne ahead of the Phuon Thuong -Sanh, his right hand holds the Phat Chu (Feather Whisk); his left hand holds the string of beads called Tu Bi; carries a sword called Thu Hung Kiem (Sword of Elevation) on his back.

Heaven Union Palace holds dharma of the Religion and plays a role as the mediumistic organization of humanity toward Divine Beings or as a bridge between the material world (Nine Sphere Palace) and Genis, Saints, Immortals, Buddha Spirits (Eight Trigram Palace)

\section{Nine Sphere Palace}

Nine Sphere Palace is the middle part of the Holy Temple, contiguous to Heaven Union Palace and Eight Trigram Palace. Under the view from outside, Nine Sphere Palace has a red tile roof and a Dome of Canonisation in the middle. The Dome has two storeys: the lower in square shape and the upper with its half dome architecture resembles an Islamic mosque and is portrayed as a globe. On the top of the globe is the statue of a Dragon -Horse carrying a Yellow River Map and running to the West but his head turns toward the East. Under the porch roof of Nine Sphere Palace, there are various decorations in grape - and grape vines shape and depictions of a couple of cranes flying on the beach at dawn.

Inside Nine Sphere Palace, the main hall is divided into 3 compartments, therein 9 steps with at $18 \mathrm{~cm}$ intervals each other lead to Eight Trigram Palace, the main hall is the place for Dignitaries, sub -dignitaries and followers to worship. In this palace, 18 pillars are divided into two parallel lines, the pillar was decorated with green dragon relief carving. The ceiling dome was painted as an emerald sky with white clouds and hundreds of stars therein. There are six dragon carved sculptures in the middle of the main compartment's ceiling (two yellow dragons, two green dragons, two red dragons) surrounded by blue sky. At two sides, the sculptures of Unicorn (Qilin), Turtle and Phoenix appear on the flat ceiling. These creatures together with the Dragon at the pillars are four sacred creatures. Each side of the main hall has a Pulpit which is raised 
stand and to be upheld by six fountain rays of dragon.

On the walls of two sides, the image of lotus flowers, seed pods and branches was carved in the rectangle pattern, amidst the pattern, Divine Eye enclosed in a triangle and surrounded by 16 rays of Glory, In intervals part between Nine Sphere and Eight Trigram Palace, there are seven thrones being red metallic painted and arranged into following order: a dragon carved throne of Pope, three phoenix carved thrones of Censor -Cardinals, three unicorn carved thrones of Cardinals. A picturesque dragon carved lattice panel screened the seven thrones. Eight Immortals' weapons were decorated alongside the thrones. There are six gates through each side of Holy Temple, and a stair with its rise steps and two statues of Kim Mao Hau guarding at two sides.

Eight Trigram Palace

Eight Trigram Palace is the last part of Holy Temple, contiguous to Nine Sphere Palace. Under the view from outside, Eight Trigram Palace has yellow tile roof and a statue of Trimurti on the top sculpting three Buddhas: Brahma Buddha faces to the West, stands on the back of a Swan, holds a mudra with the right hand and a precious pearl in the left hand, Krisna Buddha - an avatar of Vishnu, faces to South, stands on a creature called Giao -Long with an arms akimbo and the other are leaning to a Sword. Siva Buddha faces to the North, stands on seven heads serpent and to be whistling a flute.

There are 12 steps in Eight Trigram Palace, each step is 10 meters high and has eight edges, upper steps are gradually narrowed towards the center as motif of a pyramid. The step which is contiguous to Nine Sphere Palace is called Cung Đạo (Inner Sanctum). The ceiling dome of Inner Sanctum was depicted as a sky dome, in the middle of the ceiling is an ellipse shape with rays of glory in short and long size alternating each other. In this ellipse, there is a sculpture of Divine Eye at the middle, a man stands for humankind, Great Corbeille -à -Bec and Ordinary Corbeille -à -Bec with ouija board, a three legs turning -table, a bamboo bucket with fortune telling sticks therein. A sculpture in the shape of letter M appears in front of the top of Inner Sanctum; statues of Buddhas, Immortals, Saints and Genis was sculpted in a certain order: the highest raw has three statues (Lao Tzu, Sakyamunī and Confucius) the middle raw has the statue of Guanyin (Kwan Yin), of Li Tai Pei and of Guan Yu (Kwan Kong); Below the statue of Li Tai Pei, there are two statues (of Jesus Christ and Jiang Ziya).

There is a sculpture on the left of the Inner Sanctum with the statue of Eight Immortals (Li Tieguai, Zhongli Quan, Lu Dongbin, Han Xiang Zi, He Xiangu, Lan Caihe, Zhang Guo Lao, Cao Guojiu). The sculpture on the right carved the statue of Seven Deities (Li Jing, Nezha, Muzha, Jinzha, Vi Ho, Yang Jian, Loi Chan Tu). In Eight Trigram Palace, there is a Cosmos Globe with blue sky and 3.072 stars on its surface. The Divine Eye was depicted in the Big Dipper constellation. In front of the Cosmos Globe is an altar 
with the following ritual objects: An oil lamp always burning (called as Taiji lamp or Supreme Monad lamp). There are two lamps on two sides of the altar (called as Liangyi lamps or Yin-Yang lamps), a flower vase, a fruit plate, three cups of wine, a cup of tea, a cup of purified water, an incense burner. Under the Cosmos Globe, there are tablets of Divine Beings (Genis, Saints, Immortals, Buddhas and Martyrs). The ashes of Superior dignitaries have been put in an underground octagonal tunnel (called as Tàng Bửu Khánh)

\section{Symbolic meanings of the Holy Temple}

The anthropologist Clifford Geertz argued that: "A religion is a system of symbols which acts to establish powerful, pervasive, and long -lasting moods in men by formulating conceptions of a general order of existence and clothing those conceptions with such an aura of factuality that the moods and motivations seem uniquely realistic" (Dương Ngọc Dũng, 2014).

To comprehend Caodaism Holy Temple's symbolic meanings, we have to decode the most important symbol Holy Temple at first. The Holy Temple has not only spiritual symbolic meaning as the worldly White Jade Palace where God and Divine Beings reign and but also following meanings:

- Philosophical aspect: The Holy Temple is the symbol of Tao (the Way) and also of "Cosmos and Cosmological principles". It was built as an archetype of sacred creature Dragon -Horse. In a distant visual view, the Holy Temple appears as a Dragon -Horse. His head is Heaven Union Palace with Drum and Bell Tower as two horns, his body is Nine Sphere Palace with a symbol of Yellow River Map on the top of Nghinh -Phong Dai (Dome of Canonisation) and his tail is Eight Trigram Palace.

Holy Temple is the most numerous place of Caodaism and figurative symbol of Dragon -Horse, a sacred creature that has an intimate spiritual meaning in Eastern culture. Dragon -Horse is figured as a particular sacred creature with the head of a Dragon, the body of a Horse being covered with Dragon scale. With the Yellow River Map on its back, the Dragon -Horse with his majestic stand and vigorous appearance seems ready to go ahead. This creature is associated with prehistoric legend. According to Caodaism Dictionary of Nguyen Van Hong, it is legendry refers to Dragon -Horse as follows:

"In prehistoric time in China, Fu Hsi Dynasty (2852 -2737 BCE), there is a sudden tempest on the Yellow River and then the river water fiercely increased, meanwhile a supernatural creature appeared with its shape consisting of a dragon head and horse body. The creature stood quite far, over the river surface. On its back, there were several black and white dots arranged in a specific logical order and a precise sword. Emperor $\mathrm{Fu} \mathrm{Hsi}$ was promptly informed about this supernatural story. He got to the riverside right away and then observed. It is said that $\mathrm{Fu} \mathrm{Hsi}$ is a Deity emperor, thus he 
recognized the sacred creature Longma (Dragon -Horse) rarely appeared. Then he said to the Dragon Horse: "If you bring a treasure to me, then let come here, come before me". Dragon -Horse seemed to make sense of these words, he slowly came to the riverside and knelt down before the Emperor. Then, Fu Hsi saw a diagram shaped from 55 dots on Dragon -Horse's back and took the precious sword after he remembered the order of dots. Right away, the Dragon -Horse returned to the ocean and then disappeared resulting in the withdrawal of Yellow River water. Emperor Fu Hsi re drew all dots on the back of Dragon -Horse onto a map named Yellow River Map. As observation of the dots along with natural phenomena in Earth, the Emperor thought up the way to symbolize Yin Yang resulting in the creation of Eight Trigram Map (also called Earlier Heaven Eight Trigram Map” (Duc Nguyen, 2010).

According to Caodaism doctrine, Dragon -Horse shape is combined by Dragon and Horse. The Dragon frequently appears and then disappears in the clouds, struggling all over the sky. So it symbolizes space, also refers to magnanimity, strong power, flexibility, and belongs to Yang. The Horse is a useful animal in the world, laid its run steps on land, endurance, belongs to Yin. Horse runs fast while slow, symbolizing time. Therefore, Dragon -Horse is an embodiment of the union of Yin and Yang which indicates to the Tao (the Way). The I Ching doctrine stated that "One yin one yang constituted the Tao" which means as one Yin and one Yang interacts with one another, the Tao is created, transformed and formed into everything in the Universe. That is an unceasing cycle in all interrelations among Heaven, Earth and Human within the dualism theory of Yin and Yang.

On the other hand, as Dragon -horse bears a combined meaning of Dragon (symbol of space) and Horse (symbol of time), it also signifies to the Universe. In semantic aspects of Han characters (Hanzi), "Universe (宇宙)" is composed of space and time, and the word “宇” means space, while “宙” means time. As it was defined by Chu Hsi "Four directions, the upper, the lower are space, the past, present and future are time" (Nguyễn Trung Hậu, 2010).

The Dragon -Horse indicates to the Tao, to the harmony of Yin and Yang, to emergence and transforming of everything, also signifies to the vast and occult Universe which is everlasting in its work and evolution based on constant principles. That is the reason why the Holy Temple is built as an archetype of Dragon -Horse. Furthermore, in part of Nine Sphere Palace, on the top of Dome of Canonisation, there is a statue of a Dragon horse running to the West but its head turns toward the East. This statue indicates to "The Tao originated in the East", the Tao later spread to the West but it will definitely return in the final, because the East is its origin. It follows circulation and returns to the origin, to ancient values. According to this meaning, Caodaists believe that the Religion 
was founded in Vietnam (an Eastern country) and will spread over the West in the future. But finally, it will return to Vietnam - the Holy Land was allocated by Supreme Beings

- Caodaism esoteric teachings: The Holy Temple bears a meaning of the unity of Three Treasures. In Caodaism doctrine, Three Treasures of the Tao are Buddha - DharmaSanga, of the human are Tinh (Body), Khi (Vital energy), Thần (Soul). Three Treasures show their visual correspondence via three parts of the Holy Temple: Nine Sphere Palace, Heaven Union Palace and Eight Trigram Palace. Nine Sphere Palace signifies to "Tinh" (Body), "Sangha", this is a place on which dignitaries, sub -dignitaries and adherents worship the Supreme Beings. This palace is also referred to as both the "body" and administrative organization of the Religion. Heaven Union Palace is a mediumistic place where Nine Sphere Palace's dignitaries communicated to Divine Spirits in Eight Trigram Palace. All wills of God, religious doctrines, laws and regulations, rituals... have been given at Heaven Union Palace. According to the New Canonical Codes and the Religious Constitution of Caodaism, Heaven Union Palace remains the function as a judicial organization of the Religion. This part plays a role as the "Chon Than" (perispirit, vital essence), remains the corporal body in its normal work. Thus, Heaven Union Palace stands for "Khi" - Perispirit, the air, "Dharma" religious teachings; The Eight Trigram Palace points to "Thần" - soul, brain and "Buddha" since in here the Supreme Being and Divine spirits of Buddhas, Immortals, Saints and Genies descended and gave spiritist guidance resulting the founding and growth of Caodaism. The unity of Three Palaces results in the intelligence and wisdom of humankind. The one in the absence of soul will die, in the absence of perispirit will be out of his mind, in the absence of corporal body will not become a human, it meant the matter and spirit cannot be separated (Phạm Tấn Đãi, 1961).

Through internal spiritual alchemy, Caodaism suggests four stages towards the unity of Three treasures: to purify the material body, the vital energy and soul, then to return to the Tao (Wu ji). One will achieve enlightenment and immortality. As a badge of the unity of Tinh (material body) - Khí (Vital energy) - Thần (Soul), the Holy Temple was built as a reminder about an enlightened -toward place where humans should return to.

\section{Symbolism of the Holy Temple in the relationship to Southern culture}

Southern Vietnam is a prosperous region and a new explored land with its more than 300 years history. Many races including Vietnamese, Khmers, Chinese, Cham etc. have emigrated to the new territory. Vietnamese are the majority amongst them. The coexistence duration associated with the exploration within a similar natural environment region led to cross -cultural exchange and acculturation, all of them constituted a distinguishing characteristic culture. 
From geo -political and geo -cultural perspectives, the Southern region meets many essential elements to being a cultural, poli9tical and economic center. As a result, the acculturation rapidly processed in multi -perspectives and multi -realms, either in quality or quantity. Especially, the process of cross -cultural exchange and acculturation vigorously proceeded due to Western cultural contact, resulting in various cultural characteristics of the Southern region. Such scenario linked to Caodaism's antecedent; so this Religion has been deeply influenced by Southern culture as claimed by Huynh Ngoc Thu as: "Before the birth of Caodaism, the Southern Vietnam had been a center of cultural convergence of diverse flows of culture from racial traditional cultures to Western culture. By the way of blending all of these elements, Southern culture became rich and diverse; consequently composed of special syncretic aspects of the Southern region" (Huỳnh Ngọc Thu, 2017).

Caodaism has been claimed for lots of fresh cultural values rooted in Southern culture, these values do not just reflect themselves on ideology, organizational system, rituals, costumes, even on the symbols in religious architecture. In an overall perspective of the architecture of the Holy Temple in Tay Ninh Holy See, this architecture is an embodiment of "eclecticism" between the architecture of the West and the East, of France and the Southern traditional shrines and temples. This feature constituted a solemn beauty as well as spontaneity and peace. The architecture of Holy Temple thus is known as a syncretic architectural style created by Vietnamese in the Southern region.

Most importantly, cultural values of the Holy Temple symbol do not only present in the harmony of West and East or Ancient to Present, but also enhance itself as a symbol of community attachment. In view of religious symbolism, the Holy Temple is a worship place of the Supreme and other Holy Spirits. However, in view of sociology, the Holy Temple is an emblem of the attachment of the Caodaist community. This attachment differed upon social hierarchy, and to be cultivated by religious affection which especially bears occult features. The Caodaist community supposed that they can be proud of the Holy Temple which exalted Caodaism from other religions, and with its history and construction circumstance, to be a spiritual pillar of the Faithful. Thus, even a small change in the architecture of the Holy Temple also can cause pondered concerns of Caodaists. The way that they make good deeds as cleaning, tidying up the Holy Temple reveals their delight, respect, and pride of the Holy Temple.

\section{Conclusion}

The Holy Temple is honored by Caodaists as the worldly White Jade Palace where God and Divine Beings reign, it contains miraculous secrets about exoteric and esoteric teachings, is an unique embodiment of Eastern - Western architecture with strong 
influence of Baroque style in Southern Vietnam reflecting by exuberant and precious decorations. Moreover, people in several classes recognized that the building also implies to Vietnamese architectural traditional characteristics which are corresponding to domestic natural environment and social factors.

The Holy Temple enriched the unique figures of Caodaism together with emblemed spiritual values and enhanced the sacredness and solemnity of this Religion. In a certain perspective, the Holy Temple did not only herald religious ideology but also indicated cultural exchange and acculturation. This claim was developed by the harmony of West and East and the spirit of Three Religions' unity in the architectural symbolism of the Holy See. The Holy Temple symbol contributed a greater tolerance towards contrary points of view, religious discriminations, and spread closeness and love.

By exploring symbolism of the Holy Temple, we found out that Caodaism's symbols provided a value chain from morality to rationality to even aesthetics, and demonstrated aspirations of Southern Vietnamese people about ideal society towards freedom, peace, and love. Especially "nostalgic" features can be uncovered under the symbolic veil, it meant to return to the old day with a hope to revitalize forgotten values. Summing up, it may be asserted that Caodaism is a significant part of life of faith in Vietnam and has a positive impact on culture in the Southern community.

Conceivably, the studies on Caodaism in general and Caodaist symbolism in particular have not ever been a fresh subject, but further research is needed in order to discover various veiled issues and aspects.

\section{References}

Dang Nghiem Van (1995). Bước đầu tìm hiểu Đạo Cao Đài [The first step to understand Caodaism]. Social Sciences Publishers, Hanoi.

Dinh Hong Hai (2014). Nghiên cứu biểu tuợng một số hướng tiếp cận lý thuyết [Symbolism Studies: Approaching Theoretical Methodology]. The Gioi Publishers, Hanoi.

Dong Tan (1967). Lịch sử Cao Đài (phần Vô vi) [History of Caodaism (Wuji Section)]. Cao Hien Publishers.

Duong Ngoc Dung (2014). Tôn giáo là gì [What is the Religion]. Science and Technology Development Journal, 17(X5).

Duc Nguyen, 2010. Cao Đài Từ điển [ Dictionary of Caodaism]. The Sacerdotal Council's Rights reversed.

Faculty of Anthropology (2010). Nhân học đại cuoong [An introduction to Anthropology]. National University HCMC Press.

Huynh Ngoc Thu (2017). Đạo Cao Đài ở Việt Nam và các mối quan hệ [Social Functions of Caodaism in Vietnam]. National University HCMC Publishers.

Minh Quang (2011). Ai cập sinh tử kỳ thu [Egyptian Book of the Dead]. Hong Duc Publishers. 
Nguyen Long Thanh (2014). Danh hiệu Đại Đạo Tam Kỳ Phổ Độ [The official name of The Great Way of The Third Amnesty Era]. Phuong Dong Publishers, HCMC.

Nguyen Thanh Xuan (2005). Một số tôn giáo ở Việt Nam [Religions in Vietnam]. Ton Giao Publisher, Hanoi.

Nguyen Trung Hau (2010). Thiên Đạo [Heaven Tao]. Ton Giao Publisher, Hanoi.

Pham Tan Dai (1961). Giải thích nội tâm và ngoại tâm Đền Thánh Cao Đài Tây

Ninh [An explanation about the inside and outside of Caodaism Holy Temple in Tay Ninh]. https://tusachcaodai.files.wordpress.com

Tay Ninh Holy See (1969). Thánh ngôn hiẹp tuyển [Compilation of Divine Messages]. The Sacerdotal Council's Rights reversed.

Tay Ninh Holy See. Đạo Sü [History of the Religion]. The Sacerdotal Council's Rights reversed.

Tran Khanh Hung (2014). Hai truyền thống trong nghiên cứu biểu tượng (bản thảo) [The two traditional approaches on symbolism study (draft version)]. Social Sciences Journal no. 5.

Tran Ngoc Them (2011). Cơ sở văn hóa Việt Nam [Introduction to Vietnamese Culture]. Giao Duc Publisher.

Tran Thu Dung (2019). Dấu ấn tam điểm trong văn hóa, nghệ thuật [Masonic imprints in artistic culture]. Da Nang Publisher.

Tran Trong Kim (2003). Nho giáo [Confucianism]. Van Hoc Publisher.

Tran Van Rang (2017). Đạo nghiệp của Hộ pháp Phạm Công Tắc [The religious life of Ho Phap Pham Cong Tac]. Phuong Dong Publishers, HCMC. 